University of Tulsa College of Law

TU Law Digital Commons

Articles, Chapters in Books and Other Contributions to Scholarly Works

2009

\title{
Participation and the Right to Health: Lessons from Indonesia
}

Sam Halabi

Follow this and additional works at: http://digitalcommons.law.utulsa.edu/fac_pub

Part of the Law Commons

\section{Recommended Citation}

11 Health and Human Rights 49 (2009).

This Article is brought to you for free and open access by TU Law Digital Commons. It has been accepted for inclusion in Articles, Chapters in Books and Other Contributions to Scholarly Works by an authorized administrator of TU Law Digital Commons. For more information, please contact daniel-bell@utulsa.edu. 
Sam Foster Halabi, JD, MPhil, is a Fellow at the O'Neill Institute for National and Global Health Law, Georgetown University Law Center.

Please address correspondence to the author at the O'Neill Institute for National and Global Health Law, 600 New Jersey Ave. NW, Fifth Floor, Hotung Building, Washington, DC 20001, email: sfh9@law.georgetown.edu.

\section{Competing interests: None} declared.

Copyright (C) 2009 Halabi. This is an open access article distributed under the terms of the Creative Commons Attribution Non-Commercial License (http://creativecommons.org/ licenses/by-nc/3.0/), which permits unrestricted non-commercial use, distribution, and reproduction in any medium, provided the original author and source are credited.

\section{PARTICIPATION AND THE RIGHT TO HEALTH: LESSONS FROM INDONESIA}

\section{Sam Foster Halabi}

\section{ABSTRACT}

The right to participation is the "the right of rights" — the basic right of people to have a say in how decisions that affect their lives are made. All legally binding international human rights treaties explicitly recognize the essential role of participation in realizing fundamental buman rights. While the substance of the buman right to health has been extensively developed, the right to participation as one of its components has remained largely unexplored. Should rights-based health advocacy focus on participation because there is a relationship between an individual's or a community's active involvement in health care decision-making and the highest attainable standard of health? In the context of the buman right to bealth, does participation mean primarily political participation, or should we take the right to participation to mean more specifically the right of persons, individually and as a group, to shape health care policy for society and for themselves as patients? Decentralization of bealth care decision-making promises greater participation through citizen involvement in setting priorities, monitoring service provision, and finding new and creative ways to finance public bealth programs. Between 1999 and 2008, Indonesia decentralized bealth care funding and delivery to regional governments, resulting in substantial exclusion of its poor and uneducated citizens from the bealth care system while simultaneously expanding the opportunities for political participation for educated elites. This article explores the tension between the right to participation as an underlying determinant of bealth and as a political right by reviewing the experience of Indonesia ten years after its decision to decentralize health care provision. It is ultimately argued that rightsbased advocates must be vigilant in retaining a unified perspective on buman rights, resisting the persistent tendency to separate and prioritize the civil and political aspects of participation over its social component.

\section{INTRODUCTION}

The right to participation is the "the right of rights" — the basic right of people to have a say in how decisions that affect their lives are made. ${ }^{1}$ All legally binding international human rights treaties recognize the essential role of participation in realizing fundamental human rights. The United Nations Committee on Economic, Social and Cultural Rights, in its 2000 General Comment No. 14, The Right to the Highest Attainable Standard of Health, provides that participation of the population in all health-related decision-making at the community, national, and international levels is an important aspect of the right to health. ${ }^{2}$ Paragraph $43(\mathrm{f})$ of General Comment No. 14 directs states to use participatory methods to adopt and implement a national public health strategy and implement a plan of action to achieve it. Article 4 of the 1978 Declaration of Alma-Ata on Primary Health Care states that "people have the right and duty to participate individually and collectively in the planning and implementation of their health care."3

Within the literature on the right to health, there is no conceptual clarity about the role that participation plays for individuals in attempting 
to obtain the highest attainable standard of health, as human rights law mandates. ${ }^{4}$ Should rights-based health advocacy focus on participation because there is a relationship between an individual's or a community's active involvement in health care decisionmaking and the highest attainable standard of health? In the context of the human right to health, does participation mean primarily political participation, or should we take the right to participation to mean more specifically the right of persons, individually and as a group, to shape health care policy for society and for themselves as patients? As Neil Popovic phrased it, "[D]oes [the right to participate] matter for its own sake (the elemental model), or as a means to protect... other cherished values (the instrumental model)?"5

In the context of the right to health, these two types of participation are best understood with reference to 1) General Comment 14, which, along with food, nutrition, housing, healthy occupational and environmental conditions, and access to health-related education and information, lists participation as an "underlying determinant[ ] of health;" and 2) the 1993 Vienna Declaration and Programme of Action, which calls for "the freely expressed will of the people to determine their own political, economic, social and cultural systems." ${ }^{\prime \prime}$ With the former approach, participation occurs under the direction of health providers to "reduce individual illness or improve the individual's environment." ${ }^{\prime 7}$ Under the latter, citizens are decision-making stakeholders who have a say at every level, from where resources are allocated to logistical planning. ${ }^{8}$ The right to participation has traditionally been researched only in the political context, that is, involvement in decision-making, planning, and implementation processes ranging from community organization to electoral politics. That argument has been extended to health care policies. Proponents say that participatory politics are necessary to ensure participation in health care and public health planning, via elected officials and a responsive, transparent government. However, in this article, I show that the two approaches to participation are quite distinct and can be unrelated or even follow opposing trends.

Juxtaposing participation as an elemental right versus an instrumental right does not necessarily entail any contradictions. When effective community participation can contribute to improvements in individual and community health, then the elemental and instru- mental approaches converge. Yet the evidence as to the relationship between community participation and health outcomes is relatively thin. ${ }^{9}$ Practitioners often adopt an idea of community based on spatial and social factors and political ideas that may not correspond to local understandings or circumstances. ${ }^{10}$ Advocates of rights to participatory health care may overlook key challenges to meaningful participation in health care decision-making, mistaking idealized notions of "inclusion" for effective health care planning and provision. ${ }^{11}$ This apparent contradiction is easily resolved when taking both approaches into consideration, not discarding participation if its benefits are not immediately obvious, and not insisting on participation at all costs where such costs are considerable.

Politicians, scholars, and civil society groups have advanced decentralization of health care decisionmaking as a possible solution to achieving the right balance between increasing opportunities for decision-making participation and involving interested stakeholders in a way that would improve individual and community health. ${ }^{12}$ Decentralization of health care decision-making promises greater participation by involving citizens in setting priorities, monitoring service provision, and finding new and creative ways to finance public health programs. ${ }^{13}$ The theory, informed largely by political science and public choice literature, is simple: citizens understand their ability to shape health care outcomes, within parameters of general policy, if given the opportunity. ${ }^{14}$ The more local the decisions, the greater the participation. This theory depends, of course, on a careful assessment of local circumstances; decentralization without deliberation risks burdening resource-poor regions or municipalities with expensive responsibilities but insufficient information, personnel, or technology.

This article explores the realization of the right to participation as a component of the right to health, and as a political right, by reviewing the experience of Indonesia ten years after its decision to decentralize health care provision. I argue that the two perspectives on the right to participation are distinct and can run contrary to one another. Indonesia embraced the 1978 Alma-Ata principles and pushed its planning agenda through a centralized system of building health centers and training local workers. In 1995, the Indonesian Ministry of Health first studied decentralizing the public health system, and in 1999 took steps to do so within broader efforts to decentral- 
ize administrative authority. Three major factors led the Indonesian government to decentralize authority over public services, including health care, to regional governments. First, international lending institutions imposed restrictive conditions on loans made in the wake of the 1997 Asian financial crisis. Second, secessionist movements in Indonesia's peripheral provinces surged during this time period. Third, diminished public revenue in the wake of the financial crisis pushed officials to identify budget items, such as the centralized health care system, for which alternative financing arrangements could be developed. ${ }^{15}$

Indonesia adopted Law No. 22/1999 on regional governance and Law No. 25/1999 on fiscal balance, devolving powers to the regions. ${ }^{16}$ The laws gave provinces, districts, sub-districts, and villages authority over public affairs - including health — while the central government retained control over foreign policy, defense, security, the judiciary and fiscal policy, and religious affairs. ${ }^{17}$ The move to localize service sectors boosted rights-based health advocates' call for local participation. At the same time, the diminishing role of the central government eroded the previous commitment to a model of health care as a public good. ${ }^{18}$

\section{PARTICIPATION AS A HUMAN RIGHT}

Human rights are comprised of civil, cultural, economic, political, and social rights made binding as part of customary international law and at least two major international covenants: the International Covenant on Economic, Social and Cultural Rights (ICESCR), and the International Covenant on Civil and Political Rights (ICCPR). In the context of the ICCPR, the right to participation has generally been taken to mean the right to organize a political party, to vote, or to freely express political opinions. ${ }^{19}$ Other treaties define participation as the right to participate in cultural life; or, the right of children to participate in decision-making processes affecting their interests. ${ }^{20}$

The ICESCR casts participation as part of the right to health both as an "underlying determinant[] of health" and as a right to have a say in health matters, generally. The UN Committee on Economic, Social and Cultural Rights interpreted the right to health, as defined in article 12.1, as an inclusive right comprised of:

access to safe and potable water and adequate sanitation, an adequate sup- ply of safe food, nutrition and housing, healthy occupational and environmental conditions, and access to health-related education and information, including on sexual and reproductive health. A further important aspect is the participation of the population in all healthrelated decision-making at the community, national and international levels. ${ }^{21}$

On one hand, the Committee's interpretation suggests that, like potable water or a safe workplace, participation is an underlying factor contributing to health. On the other hand, the Committee separated its discussion of participation from its list of underlying factors and framed it as a "decision-making" or political aspect of the right to health.

Rights-based practitioners and scholars have focused on this latter interpretive option, analyzing participation within the meaning of the ICCPR. In her analysis of the right to health under international human rights law, Virginia Leary adopted the perspective of the Vienna Declaration, writing that:
Participation of individuals and groups in matters that affect them is essential to the protection of all human rights. Democracy and human rights are frequently linked in current rights discourse - and democracy means more than merely voting: it requires provision of information and informed participation. ${ }^{22}$

Celebrating the thirtieth anniversary of the Alma-Ata Declaration, one set of contributors to The Lancets special issue noted that the primary health care movement focused on "putting the 'public' into public health":

The inherent focus on equity, the necessity of reaching the unreached and involving them not only in the benefits of health care, but more importantly, in the decisions and actions that collectively make health, was at once novel and revolutionary. ${ }^{23}$

Yet both the fundamental documents and scholars discussing the right to health have emphasized 
its substance, that is, the basic needs the state must address that constitute factors necessary to attain the highest attainable standard of health. ${ }^{24}$ Furthermore, they stressed that health is key to participating in all other aspects of life.

Based in part on building enthusiasm for broader models of participation, other scholars elaborated detailed mechanisms for advancing participation. These include regional and national conferences and permanent or temporary forums that include providers, patients, and decision makers; localized health teams; and public meetings and focus groups to discuss policy changes. ${ }^{25}$ Under these mechanisms, citizens participate as policy-makers and as policyreviewers. Such mechanisms assume a public sufficiently informed to make policy suggestions and demand accountability. To do so, they would need to have access to basic information to propose and monitor how the state fulfills its rights obligations. For many developing and middle-income countries, that assumption is highly unrealistic. Implementing ill-conceived mechanisms for participation may result, for example, in multiple forums in which participants cannot meaningfully voice their interests or participate in policy development for lack of knowledge or information. Such a scenario highlights the ambiguity of pursuing participation within a rightsbased approach to health for its own sake.

\section{PARTICIPATION AS A DETERMINANT OF HEALTH: THE EXAMPLE OF INDONESIA}

During the Suharto regime (1965-1998), Indonesia was centrally governed, with little authority or autonomy granted to regional and local governments. Under authoritarian rule, the right to health care was one of the few core rights retained in the Indonesian Constitution and supported financially and politically. ${ }^{26}$ The Indonesian government embraced the 1978 Alma-Ata principles, embarking on a far-reaching plan to provide access to basic health care services for all citizens. The central government supplied nearly $80 \%$ of total public expenditure at the regional level. Grants from the central government for development projects, including roads, irrigation, schools, and public health, made up the remaining $20 \%$ of local public expenditure. ${ }^{27}$

As Indonesia's Ministry of Health understood participation, its core function was to expand available resources under a national development strategy that aimed at local access to an "essential health care package" that would raise the national standard of living, particularly that of the rural poor who faced higher levels of social and economic exclusion. ${ }^{28}$ Gotong royong, "mutual burden sharing," aimed to match local volunteer labor with central government transfers. ${ }^{29}$ Mutual burden sharing activities included providing expanded access to toilets, maintaining common gathering places, and cleaning the floors of houses. ${ }^{30}$ These basic sanitation schemes brought about reductions in mortality at low cost. ${ }^{31}$ The central government also trained teams of villagers in preventive strategies dedicated to nutrition, family planning, and immunization. ${ }^{32}$ By 1996, approximately 1.25 million volunteers, mostly women, were involved in these initiatives. The proportion of births attended by skilled health personnel increased from $40.7 \%$ in 1992 to $68.4 \%$ in $2002 . .^{33}$ Although the literature on gotong royong contains many warnings as to its cooption for government propaganda purposes, the basic success of this participatory aspect of Indonesian policy is well supported. ${ }^{34}$ For example, in their study of Indonesian women's participation in local networks, Jenna Nobles and Elizabeth Frankenberg found a positive and statistically significant relationship between participation and child health, particularly among mothers with little or no education. ${ }^{35}$

These participatory strategies complemented Suharto's program to establish community health centers (puskesmas) throughout the country in the 1970s and 1980s. ${ }^{36}$ The program realized full national health care coverage by the late 1980s, and encompassed 900 general hospitals and 7000 puskesmas by $1998 .^{37}$ These centers charged low user fees with the intention of thus ensuring access to basic health care. A requirement for physicians to provide public service increased access to health care providers through an incentive scheme: more remote assignments required less public service time. The results were gains in health outcomes, such as declining infant mortality and incidence of communicable diseases like polio. ${ }^{38}$ Although Indonesia continued to lag behind other countries in the Asia-Pacific region in achieving better health metrics, gotong royong, puskesmas, and public service requirements contributed significantly to improving access to health care in Indonesia and raising health outcomes. ${ }^{39}$ Between 1980 and 1997, child mortality for children under the age of five dropped $30-40 \%{ }^{40}$ For the period 1990-1996, infant mortality rates improved in each of Indonesia's 26 regions by about $20 \%{ }^{41}$ Between 1985 and 1997, vaccination 
coverage increased from $28 \%$ to $70 \%{ }^{42}$ Like food, water, and sanitation, participation was viewed as an underlying component of improving the basic health profile of communities.

\section{POLITICAL PARTICIPATION}

Driven by the financial pressures of the 1997 financial crisis and the demands of international lenders, the Indonesian Ministry of Health modified this view of participation as burden sharing to instead emphasize community consensus and planning as a way for regions to "implement development...in the health sector, to accelerate even distribution and justice according to local problems, potential, and diversity." 43 In a report titled "Healthy Indonesia 2010," the Indonesian government, with the support of international lenders and Western aid agencies, reshaped the state's role in health care provision under three interrelated objectives: 1) advocacy; 2) health promotion/ demand generation; and 3) community participation. ${ }^{44}$ Instead of mobilizing community resources toward the common objectives of basic health care access and enhanced community health, "community participation" in the new idiom could be defined as:

village-based certification program [s] [in which] local stakeholders agree on a limited number of priority health issues, develop standards for those selected issues, and then publicly recognize and reward families that achieve and maintain those standards. These families act as models for other families to adopt new health behaviors. ${ }^{45}$

In order to realize this new vision of participation, the Ministry of Health partnered with the Coalition for Health Indonesia (Koalisi untuk Indonesia Sehat, or KUIS), which is comprised of government agencies and prominent Western and Indonesian NGOs. These NGOs held workshops and training sessions aimed at encouraging the formation of participatory bodies and setting common agendas. ${ }^{46}$ Preliminary results from these sessions showed that few medical personnel or community members knew of KUIS's activities; that when they did know of them, community members showed indifference; and that suggested preventive practices were already commonplace. ${ }^{47}$

While administrative decentralization provided opportunities for Indonesians to play a role in local health care decision-making, the quality of the available health care deteriorated, particularly for Indonesia's poor. ${ }^{48}$ Instead of playing a major role in setting standards, providing personnel and funding, and monitoring outcomes, the national Ministry of Health established minimal standards for services and public health provision with inadequate corresponding ability to secure or implement them. ${ }^{49}$ Rather than viewing health care as a public good, administrations in regions, districts, and subdistricts viewed health care as a private good that was increasingly accessible on the basis of affordability. The number of private hospitals steadily grew under the decentralized regime, while doctors increasingly used their position in community health centers to "attract patients to their own private and more expensive services." ${ }^{\prime 50}$ Without the distribution of physicians under the public service requirement, local governments paid large sums to attract physicians, or paid for their education at the University of Indonesia. Increased local outlays on health care providers corresponded with a reduction in spending for environmental or preventive measures, and "principles of universal access and solidarity in health services [yielded] to a market-based ideology and an increasing role of private insurance companies." ${ }^{51}$ District parliaments, empowered to set user fees, focused on the more profitable curative approach to health.

Following these changes, preventable diseases that were in abatement - like dengue hemorrhagic fever, leprosy, and tuberculosis - reemerged. ${ }^{52}$ Between 1995 and 2005, childhood immunization rates fell from $70 \%$ to $60 \%$ before climbing again..$^{53}$ Between 2000 and 2006, the number of births in Indonesia that were attended by skilled health personnel averaged $66 \%$ even as the number of village midwives serving poor Indonesians was decreasing. ${ }^{54}$

The picture that emerges is one of community residents no longer participating in building community health centers or maintaining water and sanitation schemes because 1) the community health centers could not provide necessary care, and 2) the alternatives were prohibitively expensive. As Hasbullah Thabrany of the University of Indonesia's School of Public Health noted:

Devolving authority and obligation of health functions to the local governments poses threats to public health. Since the local government, including 
the local parliament, is an elected body, the chances of elected officials not having an understanding or commitment to public health are greater than in the previous "less democratic" government. ${ }^{55}$

The deterioration in Indonesia's commitment to providing health care coincided with increasing opportunities for participation in how local decisions were made. Yet as an economic and social matter, the uneducated poor have seen their ability to participate decline, as many households are at risk of impoverishment from the high cost of care. ${ }^{56}$

The threat of eroding health standards is demonstrated by Indonesia's medical card program to secure access to health care during the 1997 financial crisis. In that period, the World Bank and the Asian Development Bank partnered with the Indonesian central government to distribute health care access cards (kartu sehat) to protect poor citizens' access to health care. The health card entitled the owner and his or her family members to free services from public health care providers; these services consisted of outpatient and inpatient care, contraceptives for women of child-bearing age, prenatal care, and assistance at birth. Health cards were usually distributed through local health centers and village midwives and were based on a list of criteria that reflected need for assistance. Local leaders were given considerable discretion and distributed health cards according to their own views on local need. Distribution at the local level should have ensured that the poorest citizens would be identified and provided with medical cards. Yet the program failed to achieve many of its objectives because 1) many of the poorest citizens did not know about the cards, and 2) many cardholders did not believe they would actually receive services covered by the cards..$^{57}$

\section{THE RIGHT TO PARTICIPATION: LESSONS FROM INDONESIA}

The two interpretations of participation as a political right and as a determinant of health are not mutually exclusive. Indonesia's central government could have retained its centralized financing structure, albeit perhaps not at pre-1997 levels, together with its commitment to providing health care as a public good while at the same time establishing local, regional, and national participatory forums. Yet prominent organizations committed to a rights-based approach energetically worked in communities attempting to "put the 'public' back into public health," while overlooking that decentralization entailed jettisoning health as a public good. What are the lessons to be drawn for a rights-based approach?

Rights-based advocates must be vigilant in maintaining a unified perspective on human rights, resisting the persistent tendency to separate and prioritize civil and political rights over economic, cultural, and social rights. Political participation alone is no panacea for improving other rights, such as the highest attainable standard of health. Within the literature on participation, rights-based scholars and practitioners have consistently focused on the political right to participation, neglecting its other relevant aspects. As UN Special Rapporteur on the Right to Health Anand Grover recently noted, scholars and practitioners are creating an artificial dichotomy in Article 12 when they focus on "physical" determinants of health like adequate food and water to the detriment of "social" determinants like education and social inclusion. ${ }^{58}$

A rights-based approach views participation according to the "sensitivity" of local capacity, that is, to issues where locals have sufficient information and an individual stake, and a direct link to effecting health care outcomes. John D. Montgomery, for example, suggests that local participation makes sense for improving the diet of preschool children (where local knowledge and circumstances can have a significant effect), but not for building city sanitary systems (where local knowledge is not uniquely helpful)..$^{59}$ In the Indonesian context, the central government's commitment to building nationwide health infrastructure, while communities complemented the central effort with low-cost burdensharing, generated significant gains for both access and improved health.

Yet a rights-based approach must also remain committed to what is known as the "progressive realization" of the right to health. The concept of progressive realization is used by rights-holders or their advocates to delineate incremental obligations of duty-bearers to fulfill the right to health through, for example, increased access to essential medicines, emergency care, and pre- and post-natal care. ${ }^{60}$ In the Indonesian context, the efforts of KUSI to expand participation did not explicitly aim to increase the capacity of community members to hold their government accountable for the "essential health care package" available before decentralization and to build essential health 
care into the Indonesian Constitution. ${ }^{61}$ Since 1945 , the Indonesian Constitution has promised some degree of access to health care, and, since 2000, that guarantee has been explicit. ${ }^{62}$ Indonesia ratified the International Covenant on Social, Economic and Cultural Rights and implemented domestic enacting legislation in $2005 .{ }^{63}$ The deterioration of the central government's commitment to provide health care raises the urgency of incorporating human rights into the regular and professional conduct of providers. ${ }^{64}$

A rights-based approach requires a dialogue between practitioners, policy makers, and participants with the aim of educating and providing participants with information, not only about health or sanitation, but also about their rights to quality care. KUIS is one example of practitioners who define successful participation in health care provision merely as participants' contributions to prioritize their own needs; rates of voluntarism; utilization; and financial contribution. ${ }^{65}$ Similarly, many advocates practice a narrow interpretation of the kind of information they must share with patients and community members. A rights-based approach to health requires not only participation via these types of solicited information contributions, but also an interactive campaign of promotion and education about human rights.

The failure of the kartu sehat scheme (which still operates despite known, persistent weaknesses) mirrors the underlying state of Indonesians' knowledge of their human rights. In his recent survey of efforts to litigate social and economic rights in Indonesia, Bivitri Susanti noted that $97 \%$ of Indonesians with no formal education were unable to name a single basic human right to which they were entitled ${ }^{66}$ Although anthropologists, lawyers, and human rights-activists have studied the awareness of human rights in both rural and urban populations, similar studies in the right-to-health literature are scarce. ${ }^{67}$

Addressing the gaps in information faced by local participants and reaching across areas of human rights activism will play fundamental roles in realizing the human right to participation as both an end and a means. Citizens armed with knowledge of human rights are better equipped to demand action from local government and hold it accountable. Rights-based advocates are well-positioned to encourage the incorporation of human rights curricula into Indonesia's growing number of educational institutions for public health professionals. Because institutions are being established rapidly (although perhaps not thoughtfully, as they are driven largely by the promise of tuition revenues), the comprehensive nature of this essential education is currently being compromised. ${ }^{68}$

Besides holding local governments accountable, informed citizens may also be able to force governmental accountability through legal action, although that promise is distant. In the words of A. Patra M. Zen, "[economic and social] rights in principle have become constitutional rights, but they have not become rights. That is to say, they cannot be enforced using the domestic legal framework." "69 While the Indonesian judiciary continues to confront serious corruption and bureaucratic challenges, civil society organizations are increasingly effective at using the courts to vindicate rights or draw attention to public health threats. ${ }^{70}$ In 2003, a Jakarta court ordered the government to take "necessary concrete measures" to feed, shelter, and provide medical care to migrant laborers who had been expelled from Malaysia. ${ }^{71}$

Whether through local activism or through the national judiciary, health professionals are uniquely positioned to provide local residents with important information regarding their health, including human rights. On a day-to-day basis, these professionals are already actively translating traditionally conceived "health information" into the local vernacular. Rights-based public health professionals are aware of the major conventions establishing fundamental rights and can communicate that understanding to their patients as well as to other individuals in the community. $^{72}$

\section{CONCLUSION}

While the Vienna Declaration officially ended the indivisibility of political rights and social rights, the distinction persists in important scholarly and policy-making circles. The right to participation presents a unique challenge for the effective realization of the Vienna Declaration's unifying aim. ${ }^{73}$ In the Indonesian context, the expansion of political participation occurred contemporaneously with a diminishing commitment to access to basic health care. ${ }^{74}$ Civil society groups committed to the environment, public health, and the rule of law supported not only the downfall of Suharto but the decentralization of political authority in the name of political participation. ${ }^{75}$ However, the result of decentralization has 
not improved health outcomes or bolstered political participation among Indonesia's poorest and most marginalized citizens.

Participation as a component of the right to health requires a commitment to the idea set forth by the UN Committee on Social, Economic and Cultural Rights that " $[\mathrm{h}]$ ealth is a fundamental human right indispensable for the exercise of other human rights." 76 In his essay challenging public health orthodoxies in health and human rights, Paul Farmer phrased it this way:

In short, I advocate, as a public health activist, reversing the present priority which places civil and legal rights first and adjourns substantive rights for another day. It is when people are able to eat and be well that they have the chance to build democratic institutions. ${ }^{77}$

We must recognize, first, that access to health care is and must be a public good from which no person can be excluded as a matter of right. We must also recognize that participation as a component of the right to health is different from, yet works in partnership with, participation as political inclusion; and that "health information" and "human rights information" are equally important to realizing the highest attainable standard of health. Until we recognize all three of these principles, the existing commitment to political participation remains one that is misdirected, since it may not only fail to achieve improved health for communities, but may delay the more meaningful ability to have a say in how decisions are made that affect their lives.

\section{ACKNOWLEDGMENTS}

The author wishes to thank Crystal Johnson for assistance in understanding the Indonesian environmental movement's use of litigation, and Jenelle Beavers and Christoph Wilcke for their helpful comments.

\section{REFERENCES}

1. J. Waldron, "Participation: The right of rights," Proceedings of the Aristotelian Society 98 (1998), pp. 307-337.

2. Committee on Economic, Social and Cultural Rights, General Comment No. 14, The Right to the Highest Attainable Standard of Health (Article 12),
U.N. Doc. No. E/C.12/2000/4 (2000). Available at http://www.unhchr.ch/tbs/doc.nsf/(symbol)/ E.C.12.2000.4.En.

3. Available at http://www.who.int/hpr/NPH/ docs/declaration_almaata.pdf.

4. V. A. Leary, "The right to health in international human rights law," Health and Human Rights: An International Journal 1 (1994), p. 32.

5. N. Popovic, "The right to participate in decisions that affect the environment," Pace Environmental Law Review 10 (1993), pp. 684-685.

6. Committee on Economic, Social and Cultural Rights, General Comment No. 14, (see note 2), Para. 4, 11; United Nations, World Conference on Human Rights: Vienna Declaration and Programme of Action, Vienna, June 14-25, 1993, UN Doc. No. A/CONF.157/24 (1993), Article 8. Available at http://www.unhchr.ch/huridocda/huridoca.nsf/ (Symbol)/A.CONF.157.23.En?OpenDocument.

7. J. Church et al., "Citizen participation in health decision-making: Past experience and future prospects," Journal of Public Health Policy 23/1 (2002), p. 13.

8. Ibid.

9. C. Wayland and J. Crowder, "Disparate views of community in primary health care: Understanding how perceptions influence success," Medical Anthropology Quarterly 16/2 (2002), pp. 231-232.

10. Ibid; D. Zakus and C. Lyzack, "Revisiting community participation," Health Policy and Planning 13/1 (1998), pp. 1, 6.

11. This is especially true in Indonesia, where ethnic diversity has a significantly negative effect on efforts at community participation; see C. Okten and U. Okonkwo Osili, "Contributions in heterogeneous communities: Evidence from Indonesia," Journal of Population Economics 17/4 (2004), p. 603.

12. R. Lakshminarayanan, "Decentralisation and its implications for reproductive health: The Philippines experience," Reproductive Health Matters 11/21 (2003), p. 102.

13. S. Lieberman, J. Capuno, and H. Van Minh, "Decentralizing health: Lessons from Indonesia, the Philippines and Vietnam," in World Bank, East Asia decentralizes: Making local government work (Washington, D.C: World Bank: 2005), pp. 155-157. 
14. B. C. Smith, "The decentralization of health care in developing countries: organizational options," Public Administration and Development 17 (1997), p. 399.

15. S. Kristiansen and P. Santoso, "Surviving decentralization? Impacts of regional autonomy on health service provision in Indonesia," Health Policy 77/3 (2006), pp. 247-259.

16. G. Bell, "The new Indonesian laws relating to regional autonomy: Good intentions, confusing laws," Asia-Pacific Law \& Policy Journal 2 (2001), p. 1.

17. B. Susanti, "The implementation of the right to health care and education in Indonesia," in D. Brinks and V. Gauri (eds), Courting social justice (Cambridge: Cambridge University Press, 2008), p. 232.

18. From a rights-based perspective, access to basic health care is a "public good" — that is, no one can be denied access on the basis of ability to pay; see L. Rubenstein, "The right to health care," (remarks at "Human Rights in the United States: Domestic Application of International Human Rights Law," November 12, 2008). According to orthodox economic theory, a public good is one that is nonrivalrous and non-excludable. A non-rivalrous good is one that may be consumed by one consumer without preventing consumption by another, and a non-excludable good may not be denied because one has not paid for it; see T. Cowen, The concise encyclopedia of economics. Available at http://www.econlib. org/library/Enc/PublicGoods.html.

\section{M. Nowak, UN Covenant on Civil and Political} Rights: CCPR Commentary. (Kehl am Rhein: N. P. Engel, 1993), p. 445.

20. Convention on the Rights of the Child (CRC), G.A. Res. 44/25, U.N. GAOR, 44th Sess., U.N. Doc. No. A/Res/44/25 (1989). Available at http:/www2. ohchr.org/English/law/crc.htm.

21. Committee on Economic, Social and Cultural Rights, General Comment No. 14 (see note 2), para. 11.

22. Leary (see note 4).

23. J. Lawn, J. Rohde, S. Rifkin, et al., "Alma-Ata 30 years on: Revolutionary, relevant, and time to revitalise," Lancet 372/9642 (2008), pp. 917-920.

24. S. D. Jamar, “The international human right to health," Southern University Law Review 22 (1994), pp. 1-68.
25. F. Scutchfield, C. Ireson and L. Hall, "The voice of the public in public health policy and planning: The role of public judgment," Journal of Public Health Policy 25/2 (2004), pp. 197-205.; H. Potts, "Participation and the right to the highest attainable standard of health" (presentation at The UN Special Rapporteur on the Right to the Highest Attainable Standard of Health: Looking Back and Moving Forward, September 25-27, 2008). Available at http://www.ifhhro.org/files/Helen $\% 20$ Potts $\% 20$ -\%20WG10.ppt\#272,6.

26. Susanti (see note 17).

27. A. Booth, "Intergovernmental relations and fiscal policy in Indonesia: The national impact of equity and inequality in provinces" in C. Fletcher (ed), Equity and development across nations: Political and fiscal realities (New York: St. Martin's Press, 1996), pp. 180-206.

28. M. El-Naggar, "More than twenty years of community action for health," Regional Health Forum $1 / 2$ (1996), p. 3.

29. C. Okten and U. Okonkwo Osili, "Contributions in heterogeneous communities: Evidence from Indonesia," Journal of Population Economics 17/4 ( 2004), pp. 603-626.

30. B. Mitchell, "Sustainable development at the village level in Bali, Indonesia," Human Ecology 22/2 (1994), p. 206.

31. Kristiansen and Santoso (see note 15).

32. El-Naggar (see note 28).

33. WHO, The Millennium Development Goals for Health: A review of the indicators. (Jakarta: WHO Indonesia, 2002).

34. R. van Niel, "Review," Journal of Asian Studies 56/4 (1997), pp. 1153-1155.

35. J. Nobles and E. Frankenberg, "Mothers' community participation and child health," California Center for Population Research On-Line Working Paper Series. Available at http://www.ccpr.ucla.edu/ ccprwpseries/ccpr_016_06.pdf.

36. P. van Eeuwijk, "Health care from the perspective of Minahasa villagers, Indonesia," in L. Whiteford and L. Manderson (eds), Global health policy, local realities: The fallacy of the level playing field (Boulder, CO, and London: Lynne Rienner, 2000), p. 90. 
37. A. Thind, "Analysis of health services use for respiratory illness in Indonesian children: Implications for policy," Journal of Biosocial Science 37/2 (2005), pp. 129-142.

38. C. Simms and M. Rowson, "Reassessment of health effects of the Indonesian economic crisis: Donors versus the data," Lancet 361/9366 (2003), pp. 1382-1385.

39. Ibid.

40. BAPPENAS, BPS, and United Nations Development Programme, Towards a new consensus: democracy and human development in Indonesia: Indonesia buman development report (Jakarta: United Nations

Development Programme, 2001), pp. 6, 31. Available at http://www.undp.or.id/pubs/ihdr2001/ ihdr2001_full.pdf.

41. Ibid.

42. USAID, Country health statistical report Indonesia (Washington, DC: AIM 2008), p. 11.

43. Ministry of Health, Republic of Indonesia, Health development plan towards healthy Indonesia 2010 (Jakarta: Ministry of Health, 1999), p. 13.

44. Available at http://www.jhuccp.org/asia/ indonesia/2010int.shtml.

45. Ibid.

46. D. Storey, A. Ambar, and M. Lediard, Summary monitoring \& evaluation report: Healtby Indonesia 2010 initiatives July 2000-December 2002 Jakarta: Johns Hopkins University Center for Communication Programs Indonesia Country Office, 2003), pp. $17-22$.

47. Ibid.

48. Kristiansen and Santoso (see note 15). There is a general consensus around this issue, although the Asian Development Bank (ADB) and the World Bank have published conflicting data. In their essay assessing data provided by international lending institutions, Chris Simms and Mike Rowson have cast doubt as to the data: "The inconsistencies that we report suggest that the ADB's and World Bank's conclusions did not incorporate data that contradicted the notion that the social safety net provided [for the health sector, a plan known by the acronym JPS-BK] had successfully mitigated effects of the economic crisis on the health of Indonesia's poor citizens. Because the donor process was neither transparent nor consultative, the reasons for this optimistic assessment are unclear." (Simms and Rowson [see note 38], p. 1385).

49. Kristiansen and Santoso (see note 15), p. 250-251.

50. Ibid.

51. Kristiansen and Santoso (see note 15), p. 256.

52. I. Kandun, "Emerging diseases in Indonesia: Control and challenges," Tropical Medicine and Health 34/4 (2006), pp. 141-147.

53. USAID (see note 42); Center for Data and Information, Indonesian health map (Jakarta: Ministry of Health Republic of Indonesia 2007), pp. 37-39.

54. Available at http://www.globalhealthfacts.org/ country.jsp?c $=107 \& \mathrm{i}=77 \& \mathrm{cat}=6$; see also United Nations Development Program, Indonesia, Indonesia Progress Report on the Millenium Development Goals. Goal 5: Improving Maternal Health (Jakarta: United Nations Development Program, 2004). Available at http:// www.undp.or.id/pubs/imdg2004/English/MDGIDN_English_Goal5.pdf.

55. H. Thabrany, "Human resources in decentralized health systems in Indonesia: Challenges for equity," Regional Health Forum 10/1 (2006), p. 77.

56. L. P. Freedman, W. J. Graham, E. B. Brazier, et al., "Practical lessons from global safe motherhood initiatives: Time for a new focus on implementation," Lancet 370/9595 (2007), p. 1386.

57. International Labour Organization, Indonesia: Providing health insurance for the poor (Jakarta: ILO, 2008). Available at http://www.ilo.org/public/english/region/asro/bangkok/events/sis/download/ paper25.pdf.

58. A. Grover, "Key Note" (remarks at Second Human Rights and Tobacco Control Convention, Tata Institute of Social Sciences, Mumbai, India, March 13, 2009).

59. J. D. Montgomery, "When local participation helps," Journal of Policy Analysis and Management 3/1 (1983), p. 99.

60. Minister of Health v. Treatment Action Campaign (2002) 5 SA 721 (CC). 
61. An accompanying principle is the requirement of "nonregression." The UNCESCR has stated: "Moreover, any deliberately retrogressive measures in that regard would require the most careful consideration and would need to be fully justified by reference to the totality of the rights provided for in the Covenant and in the context of the full use of the maximum available resources." Committee on Economic, Social and Cultural Rights, General Comment No. 3, The Nature of States Parties Obligations (Para. 9), U.N. Doc. E/1991/23 (1990). Available at http://www.unhchr.ch/tbs/ doc.nsf/(symbol)/CESCR+General+comment+3. En?OpenDocument.

62. Susanti (see note 17), p. 233.

63. Ibid.

64. L. London, "What is a human rights based approach to health and does it matter?" Health and Human Rights: An International Journal 10/1 (2008), p. 68.

65. Wayland and Crowder (see note 9).

66. Susanti (see note 17), p. 226.

67. C. Mahler, A. Mihr, and R. Toivanen (eds), The United Nations decade for buman rights education and the inclusion of national minorities (Frankfurt am Main: Peter Lang, 2008); M. A. Ogunlayi, "An assessment of the awareness of sexual and reproductive rights among adolescents in south western Nigeria," African Journal of Reproductive Health / La Revue Africaine de la Santé Reproductive 9/1 (2005), pp. 99-112.

68. Thabrany (see note 55).

69. Susanti (see note 17), p. 228.

70. General Comment 14 adds that "any person or group victim of a violation of the right to health should have access to effective judicial or other appropriate remedies at both national and international levels [and] ... should be entitled to adequate reparation. Committee on Economic, Social and Cultural Rights, General Comment No. 14 (see note 2).

71. Susanti (see note 17), pp. 250-252.

72. S. E. Merry, "Transnational human rights and local activism: Mapping the middle," American Anthropologist 108/1 (2006) pp. 38-51.
74. L. Rieffel, "Indonesia's quiet revolution," Foreign Affairs 83/5 (2004), pp. 100-103, 106-109.

75. H. Antlöv, R. Ibrahim, and P. van Tuijl, "NGO governance and accountability in Indonesia: Challenges in a newly democratizing country," in L. Jordan and P. van Tuijl (eds), NGO accountability: Politics, principles and innovations (London and Sterling, VA: Earthscan, 2006), pp. 4-5. Available at: http:// www.justassociates.org/associates_files/Peter_ NGO $\% 20$ accountability $\% 20$ in $\% 20$ Indonesia $\% 20$ July $\% 2005 \% 20$ version.pdf; J. Gordon, "NGOs, the environment and political pluralism in new order Indonesia," Explorations in Southeast Asian Studies 2/2 (Fall 1998), pp. 47-68.

76. Committee on Economic, Social and Cultural Rights, General Comment No. 14 (see note 2).

77. P. Farmer, "Challenging orthodoxies in health and human rights" (American Public Health Association 134th Annual Meeting and Exposition Keynote Address, November 5, 2006). Available at http:/ /www.pih.org/inforesources/essays / APHA_2006_keynote-Paul_Farmer.pdf.

73. London (see note 64). 
